\title{
BIOCHEMICAL CHANGES IN THE BLOOD SERA OF SOWS WITH THE METRITIS-MASTITIS-AGALACTIA SYNDROME
}

\author{
J. RASZYK, J. ČANDERLE, M. DVOŘÁK, M. TOULOVÁ, O. MATOUŠKOVÁ \\ Veterinary Research Institute, 62132 Brno
}

Received fanuary 26, 1979

\begin{abstract}
Raszyk, J., J. Čanderle, M. Dvořák, M. Toulová, O. Matoušková: Biochemical Changes in the Blood Sera of Sows with the Metritis-Mastitis-Agalactia Syndrome. Acta vet., Brno, 48, 1979: 61-66.

Thirteen sows with the metritis-mastitis-agalactia (MMA) syndrome and 13 clinically healthy sows from a large herd of pigs where the syndrome occurred in as many as 70 per cent of the sows at one time were examined for 16 biochemical indicators in their sera before and 45 and 90 minutes after $\mathrm{i} / \mathrm{v}$ administration of $100 \mathrm{I}$. U of insulin (Spofa) on the 2 nd day after farrowing. The sows were in their second to fourth parity and farrowed from 6 to 10 live pigs. The initial values for healthy and MMA-affected animals differed significantly in the concentration of total protein, inorganic phosphorus and vitamin $\mathrm{A}$ and in the iron-binding capacity of the serum. At 45 and 90 minutes after insulin injection, significant decreases as against the initial levels were found in the concentration of glucose, nonesterified fatty acids and inorganic phosphorus in both groups. A significant rise in the concentration of 11-hydroxycorticosteroids as against the initial level was found only in healthy sows at 90 minutes after insulin injection. It is concluded that function of the hypothalamic-pituitary-adrenocortical axis of MMA-affected sows was depressed.
\end{abstract}

Substance metabolism, enzymes, vitamins, insulin, adrenal cortex, puerperium.

The metritis-mastitis-agalactia (MMA) syndrome has become a major health problem in puerperal sows under intensive husbandry conditions. Its incidence in our herds ranges between 20 and 50 per cent. Being generally accompanied by depressed milk production and changes in the appearance of sows' milk, the syndrome is responsible for increased mortality among piglets in the first days after birth, which disrupts the continuity of animal production and has an impact on farm economy. Predisposition to this disease is generally seen in morphological changes and functional incapacity of the mammary gland, injury to the teats and other parts of the udder, nervous and hormonal disorders, disturbances in substance metabolism in consequence of inadequate nutrition during pregnancy, exhaustion of the sows after farrowing, poor sanitation in the farrowing house and poor hygiene at farrowing. Organisms have not been invariably incriminated as causative agents of the syndrome, although it is generally recognized that they deteriorate and prolong the course of the disease.

Studies on sows with the MMA syndrome revealed a rise in blood progesterone and fibrinogen (Ross et al. 1975) and a lowered concentration of prolactin (Threefall et al. 1974).

Our investigations of biochemical changes in sows with the MMA syndrome were started some time ago and preliminary results have been reported (Raszyk et al. 1977; Čanderle et al. 1977). The present study was extended to include both MMA-affected and healthy sows and to investigate the dynamics of selected biochemical indicators after a standard insulin load.

The purpose of this investigation of biochemical indicators in healthy and MMA-affected sows was (1) to find whether the two groups differ in the initial levels of the indicators under study, (2) to assess their response to insulin hypoglycaemia and (3) to evaluate the functional capacity of the hypothalamo-pituitary-adrenocortical axis in these animals. 


\section{Materials and Methods}

The experiments were carried out in a herd consisting of 750 sows, mostly Large White-Landrace cross, where MMA was a serious problem. The proportion of affected sows varied during the year, amounting to 70 per cent at one time. The herd had been recently assembled and some of the buildings were still under construction. Veterinary service was provided only by a part-time veterinarian and an operator. One attendant cared for $\mathbf{4 0}$ sows in the farrowing house. The number of piglets reared per sow per year was only 13.9 animals. Since some of the buildings were still under construction, the intensive husbandry system could not be fully implemented.

The sows were fed a commercial complete feed mixture for sows. Sows in the farrowing house were fed twice a day. The feed consumption in the farrowing house per sow per day was given by the attendant as 3.5 to $3.8 \mathrm{~kg}$. The standard of management was mediocre.

Thirteen sows with the MMA syndrome and 13 clinically healthy sows were included in the experiment and examined on the 2nd day after farrowing. They were in their second to fourth parity and farrowed from 6 to 10 live pigs. The sows with MMA were divided into three subgroups according to the signs of clinical disease. Subgroup 1 comprised three sows diagnosed as hypogalactous. Their milk secretion was deficient without alterations in the general health status or inflammatory changes in the mammary gland or genitalia. Subgroup 2 comprised six sows with mastitis of one or more, for the most part hind, compartments of the mammary gland. The milk was either normal in appearance or was serous and contained clots. The general health status of these sows was impaired. The symptoms were a rise in rectal body temperature to more than $39.5^{\circ} \mathrm{C}$, listlessness and anorexia. The genitalia were clinicaly unchanged. Subgroup 3 comprised four sows diagnosed as having metritis and mastitis. In most of them an overwhelming majority of the compartments of the mammary gland were affected and showed marked hypogalactia. The general health status was impaired more than in the previous group. The rectal body temperatures were invariably above $40^{\circ} \mathrm{C}$ and there was a mucopurulent discharge from the vulva. Control sows were examined clinically on the same day as the MMA-affected animals. They showed no clinical signs of disease and their mean body temperature was $38.8 \pm 0.2^{\circ} \mathrm{C}$.

The examinations were distributed evenly over the period of the whole year. The sows were blood-sampled from the cranial vena cava for determination of the initial values, invariably in the morning after food was withheld from them for 4 hours, and immediately afterwards were each injected with $100 \mathrm{I}$. U. of insulin (Spofa) into the ear vein. The subsequent blood collections from the cranial vena cava were made 45 and 90 minutes after the administration of insulin. Blood serum was separated from the blood clot within 1 hour of blood collection and stored in a refrigerator till examination for the biochemical indicators the following day. All blood withdrawals from diseased animals had been made before therapy was started.

Sixteen biochemical indicators were evaluated in the sera of the sows. Total cholesterol was determined according to Pearson (1953) except that salicylic acid was used in place of p-toluenesulphonic acid. Nonesterified fatty acids (NEFA) were determined by the method of Duncombe (1964) as modified by Stajner and Sủva (1975). Vitamin A and E concentrations were determined fluorimetrically according to Thompson et al. (1971) and Thompson et al. (1973). 11-hydroxycorticosteroids (11-OHCS) were determined fluorimetrically by the method of Mattingly (1962) as modified by Purves and Sirett (1969). Glucose, total protein, urea, iron, iron-bindig capacity, calcium, inorganic phosphorus, magnesium, glutamic-oxalacetic transaminase (GOT), glutamic-pyruvic transaminase (GPT) and alkaline phosphatase were evaluated by means of Biolatests (Lachema, Czechoslovakia) following the manufacturers' directions. The results of the experiments were analysed statistically.

\section{Results}

I. Changes in the indicators of carbohydrate, protein and fat metabolism (Table 1)

The initial values for healthy and MMA-affected sows differed significantly only in the concentration of total protein $(P<0.05)$, which was higher in the latter. At 45 and 90 minutes after insulin injection significant decreases as against the initial levels were found in the concentration of glucose $(P<0.01)$ and NEFA $(P<0.05)$ in both groups.

II. Changes in the indicators of mineral metabolism (Table 2)

The initial values for healthy and MMA-affected sows differed significantly in the concentration of inorganic phosphorus $(P<0.01)$ and in the iron-binding 
Table 1

Indicators of carbohydrate, protein and fat metabolism in the blood sera of healthy sows and of sows with the MMA syndrome after administration of an insulin load (means \pm S. D.)

\begin{tabular}{|c|c|c|c|c|c|c|}
\hline \multirow[b]{2}{*}{ Indicator } & \multicolumn{3}{|c|}{ Healthy sows ( $n=13$ ) } & \multicolumn{3}{|c|}{ Sows with MMA (n=13) } \\
\hline & $\begin{array}{c}\text { Before } \\
\text { insulin } \\
\text { injection }\end{array}$ & $\begin{array}{l}45 \text { min. } \\
\text { after } \\
\text { insulin } \\
\text { injection }\end{array}$ & $\begin{array}{l}90 \text { min. } \\
\text { after } \\
\text { insulin } \\
\text { injection }\end{array}$ & $\begin{array}{c}\text { Before } \\
\text { insulin } \\
\text { injection }\end{array}$ & $\begin{array}{l}45 \text { min. } \\
\text { after } \\
\text { insulin } \\
\text { injection }\end{array}$ & $\begin{array}{l}90 \text { min. } \\
\text { after } \\
\text { insulin } \\
\text { injection }\end{array}$ \\
\hline $\begin{array}{l}\text { Glucose } \\
(\mathrm{mmol} / \mathrm{l})\end{array}$ & $5.00 \pm 1.59$ & $1.92 \pm 0.94$ & $1.98 \pm 1.59$ & $5.55 \pm 1.71$ & $2.15 \pm 1.38$ & $2.04 \pm 0.94$ \\
\hline $\begin{array}{l}\text { Total protein } \\
(\mathrm{g} / \mathrm{l})\end{array}$ & $63.4 \pm 16.2$ & $62.3 \pm 13.0$ & $61.3 \pm 12.3$ & $68.6 \pm 11.3$ & $65.2 \pm 6.5$ & $70.1 \pm 12.3$ \\
\hline $\begin{array}{l}\text { Urea } \\
(\mathrm{mmol} / \mathrm{l})\end{array}$ & $4.18 \pm 2.12$ & $4.29 \pm 1.62$ & $4.36 \pm 1.57$ & $5.08 \pm 2.51$ & $5.08 \pm 2.29$ & $5.08 \pm 2.54$ \\
\hline $\begin{array}{l}\text { NEFA } \\
(\mu \mathrm{mol} / \mathrm{l})\end{array}$ & $392 \pm 393$ & $241 \pm 221$ & $207 \pm 118$ & $245 \pm 246$ & $168 \pm 127$ & $139 \pm 106$ \\
\hline $\begin{array}{l}\text { Cholesterol } \\
(\mathrm{mmol} / \mathrm{l})\end{array}$ & $2.80 \pm 0.43$ & $2.98 \pm 0.63$ & $2.73 \pm 0.43$ & $2.98 \pm 0.73$ & $2.93 \pm 0.60$ & $2.70 \pm 0.43$ \\
\hline
\end{tabular}

Table 2

Indicators of mineral metabolism in the blood sera of healthy sows and of sows with the MMA syndrome after administration of an insulin load (means \pm S. D.)

\begin{tabular}{|c|c|c|c|c|c|c|}
\hline \multirow[b]{2}{*}{ Indicator } & \multicolumn{3}{|c|}{ Healthy sows $(n=13)$} & \multicolumn{3}{|c|}{ Sows with MMA $(n=13)$} \\
\hline & $\begin{array}{c}\text { Before } \\
\text { insulin } \\
\text { injection }\end{array}$ & $\begin{array}{l}45 \mathrm{~min} \text {. } \\
\text { after } \\
\text { insulin } \\
\text { injection }\end{array}$ & $\begin{array}{l}90 \text { min. } \\
\text { after } \\
\text { insulin } \\
\text { injection }\end{array}$ & $\begin{array}{c}\text { Before } \\
\text { insulin } \\
\text { injection }\end{array}$ & $\begin{array}{l}45 \text { min. } \\
\text { after } \\
\text { insulin } \\
\text { injection }\end{array}$ & $\begin{array}{l}90 \mathrm{~min} . \\
\text { after } \\
\text { insulin } \\
\text { injection }\end{array}$ \\
\hline $\begin{array}{l}\text { Iron } \\
(\mathrm{mol} / \mathrm{l})\end{array}$ & $22.1 \pm 8.3$ & $23.9 \pm 10.1$ & $20.8 \pm 9.2$ & $25.1 \pm 14.3$ & $25.5 \pm 11.0$ & $28.4 \pm 10.9$ \\
\hline $\begin{array}{l}\text { Iron-binding } \\
\text { capacity } \\
(\mu \mathrm{mol} / \mathrm{l})\end{array}$ & $88.1 \pm 18.1$ & $100.8 \pm 16.1$ & $85.7 \pm 24.5$ & $103.6 \pm 22.4$ & $100.0 \pm 14.3$ & $104.0 \pm 30.0$ \\
\hline $\begin{array}{l}\text { Calcium } \\
(\mathrm{mmol} / \mathrm{l})\end{array}$ & $1.65 \pm 0.55$ & $1.91 \pm 0.34$ & $1.85 \pm 0.22$ & $2.10 \pm 0.34$ & $1.80 \pm 0.21$ & $1.95 \pm 0.30$ \\
\hline $\begin{array}{l}\text { Inorganic } \\
\text { phosphorus } \\
(\mathrm{mmol} / \mathrm{l})\end{array}$ & $1.90 \pm 0.34$ & $1.62 \pm 0.23$ & $1.68 \pm 0.24$ & $2.08 \pm 0.36$ & $1.87 \pm 0.41$ & $1.90 \pm 0.40$ \\
\hline $\begin{array}{l}\text { Magnesium } \\
(\mathrm{mmol} / \mathrm{l})\end{array}$ & $0.66 \pm 0.17$ & $0.70 \pm 0.15$ & $0.67 \pm 0.16$ & $0.69 \pm 0.18$ & $0.68 \pm 0.20$ & $0.73 \pm 0.22$ \\
\hline
\end{tabular}

capacity of the serum $(P<0.05)$, which were both higher in the latter. At 45 and 90 minutes after insulin injection a significant decrease as against the initial levels was found in the concentration of inorganic phosphorus $(P<0.05)$ in both groups.

III. Changes in enzyme activities and vitamin and corticoid levels (Table 3)

The initial values for healthy and MMA-affected sows differed significantly in the concentration of vitamin A $(P<0.01)$, which was higher in the latter. A significant rise in the concentration of 11-OHCS $(P<0.05)$ as against the initial level was found only in healthy sows at 90 minutes after insulin injection. 
Table 3

Changes in selected enzyme activities and vitamin and corticoid levels in the blood sera of healthy sows and of sows with the MMA syndrome after administration of an insulin load (means $\pm \mathbf{S}$. D.)

\begin{tabular}{|c|c|c|c|c|c|c|}
\hline \multirow[b]{2}{*}{ Indicator } & \multicolumn{3}{|c|}{ Healthy sows $(n=13)$} & \multicolumn{3}{|c|}{ Sows with MMA $(n=13)$} \\
\hline & $\begin{array}{c}\text { Before } \\
\text { insulin } \\
\text { injection }\end{array}$ & $\begin{array}{l}45 \mathrm{~min} . \\
\text { after } \\
\text { insulin } \\
\text { injection }\end{array}$ & $\begin{array}{c}90 \mathrm{~min} . \\
\text { after } \\
\text { insulin } \\
\text { injection }\end{array}$ & $\begin{array}{c}\text { Before } \\
\text { insulin } \\
\text { injection }\end{array}$ & $\begin{array}{l}45 \mathrm{~min} . \\
\text { after } \\
\text { insulin } \\
\text { injection }\end{array}$ & $\begin{array}{c}90 \mathrm{~min} . \\
\text { after } \\
\text { insulin } \\
\text { injections }\end{array}$ \\
\hline $\begin{array}{l}\text { GOT } \\
(\mathrm{U} / \mathrm{l})\end{array}$ & $21.1 \pm 12.1$ & $20.9 \pm 9.50$ & $32.1 \pm 10.4$ & $26.0 \pm 14.6$ & $28.2 \pm 14.7$ & $26.7 \pm 15.3$ \\
\hline $\begin{array}{l}\text { GPT } \\
(\mathbf{U} / \mathbf{1})\end{array}$ & $18.5 \pm 5.9$ & $18.1 \pm 6.6$ & $19.5 \pm 4.0$ & $20.4 \pm 6.6$ & $20.5 \pm 5.0$ & $23.1 \pm 5.7$ \\
\hline $\begin{array}{l}\text { Alkaline } \\
\text { phosphatase } \\
\text { (U/I) }\end{array}$ & $32.2 \pm 14.6$ & $28.0 \pm 12.6$ & $27.1 \pm 14.4$ & $30.2 \pm 12.1$ & $31.5 \pm 14.3$ & $29.8 \pm 11.4$ \\
\hline$\underset{(\mu \mathrm{mol} / \mathrm{l})}{\operatorname{Vitamin}} \mathrm{A}$ & $0.55 \pm 0.19$ & $0.55 \pm 0.24$ & $0.60 \pm 0.21$ & $0.69 \pm 0.27$ & $0.73 \pm 0.25$ & $0.71 \pm 0.22$ \\
\hline$\underset{(\mu \mathrm{mol} / \mathrm{l})}{\operatorname{Vitamin}} \mathrm{E}$ & $2.51 \pm 0.92$ & $2.12 \pm 0.83$ & $2.39 \pm 1.01$ & $2.48 \pm 0.87$ & $2.48 \pm 1.04$ & $2.28 \pm 0.71$ \\
\hline $\begin{array}{l}\text { 11-OHCS } \\
(\mathrm{nmol} / \mathrm{l})\end{array}$ & $214 \pm 134$ & $234 \pm 131$ & $294 \pm 164$ & $169 \pm 99$ & $199 \pm 91$ & $208 \pm 155$ \\
\hline
\end{tabular}

No significiant differences were found between the three subgroups of diseased sows.

\section{Discussion}

The findings of higher serum concentration of total protein, inorganic phosphorus and vitamin $A$ and of higher iron-binding capacity of the serum in MMA-affected sows suggests that the diseased sows were not in the state of nutritional deficiency. A particularly sensitive indicator of the actual nutritional state is the iron-binding capacity of the serum, which is in fact indirect determination of transferin. This situation can be accounted for by the fact that in MMA-affected sows the amount of nutrients drawn off with the milk is smaller than in healthy nursing sows.

Similarly to the observations reported by Rose et al. (1974) no significant difference between the MMA-affected and healthy sows was found in the resting level of blood corticoids, even though the value obtained for the affected animals. was slightly lower. Wagner (1972) who tested the functional capacity of the adrenal cortex in agalactic sows by means of corticotrophin (ACTH) found no difference in the increase of blood corticoids between diseased and clinically healthy sows. However, the response to ACTH provides information only about the capacity of the adrenal to respond to this hormone and not about pituitary and hypothalamus function. In this respect, insulin hypoglycaemia is more convenient to use, since it provides information about the integrity and functional capacity of the whole hypothalamic-pituitary-adrenocortical axis (Landon et al. 1965). In contrast to the data reported by Wagner (1972) the increase in corticoids 90 minutes after insulin injection was lower in MMA-affected than in healthy sows. This finding suggests depressed function of the hypothalamic-pituitary-adrenocortical axis in sows with the MMA syndrome and supports the view that 
this syndrome is the result of in sufficient adaptation of the affected sows to intensive husbandry conditions.

However, the possibility must also be considered that the MMA syndrome may have developed secondarily in consequence of changes in the intensity and, possibly, frequency of suckling. In rats, corticosterone levels of the dams increase after nursing (Ota et al. 1974), but the reactivity to stressful stimuli is reduced during lactation (Stern and Levine 1972). In a previous study from our laboratory (Dvořák and Raszyk) the response of suckling piglets to insulin hypoglycaemia was higher than the response of healthy nursing sows in the present study.

Further evidence for hypofunction of the hypothalamus and pituitary in agalactic sows may be seen in their lower adenohypophyseal concentrations of prolactin (Threefall et al. 1974).

\section{Biochemické změny $\mathbf{v}$ krevním séru prasnic postižených syndromem metritis-mastitis-agalactie}

Ve velkochovu prasat, kde syndrom metritis-mastitis-agalactie (MMA) se vyskytoval až u $70 \%$ prasnic bylo 2 . den po porodu vyšetřeno 13 prasnic postižených MMA a 13 prasnic klinicky zdravých, po 2.-4. porodu s 6 až 10 živými selaty ve vrhu. V krevním séru obou skupin bylo sledováno 16 biochemických ukazatelů před a za 45 a 90 minut po intravenózní aplikaci $100 \mathrm{~m}$. j. Insulinu Spofa. U prasnic postižených $M M A$ byla zjištěna významně vyšší koncentrace celkové bílkoviny, anorganického fosforu, vazebné kapacity pro železo a vitaminu A. Za 45 a 90 minut po podání insulinu došlo u obou skupin $\mathrm{k}$ významnému poklesu koncentrace glukosy, neesterifikovaných mastných kyselin a anorganického fosforu. $\mathrm{K}$ významnému zvýšení koncentrace 11-hydroxykortikosteroidů za 90 minut po ošetření insulinem došlo pouze u prasnic zdravých. Bylo usouzeno na sniženou funkci osy hypothalamus - hypofýza - kưra nadledvin u prasnic postižených MMA.

\section{Биохимические изменения в кровяной сыворотке свиноматок, страдавшим метритом, маститом и агалактией}

В промышленном свиноводстве, где синдром метрита-мастита-агалактии (MМA) имел место $70 \%$ свиноматок, на второй день после опороса проводились обследования 13 свиноматок, страдавших ММА и 13 клинически здоровых свиноматок после 2-4 опоросов с 6-10 живыми поросятами в племенном гнезде. В кровяной сыворотке обеих групп проводились наблюдения за 16 биохимическими показателями до, в течение и 45-90 минут после внутривенного введения 100 м. ед. Инсулина Спофа. У страдавших MМА свиноматок была выявлена существенно более высокая концентрация общего белка, неорганического фосфора, способность связи железа и витамина А. В течение 45-90 минут после введения инсулина в случае обеих групп имело место существенное понижение концентрации глюкозы неэтерифицированных жирных кислот и неорганического фосфора. Существенное повышение концентрации 11-гидроксикортикостероидов в течение 90 минут после введения инсулина наблюдалось лишь у здоровых свиноматок. Предполагается понижение функции оси гипоталамуса-гипофиза-коры надпочечных желез страдавших ММА свиноматок. 


\section{References}

CANDERLE, J. - RASZYK, J. - VĚŽNÍK, Z. - PERNICA, A.: Možnosti prevence hypogalakcie u prasnic některými hormonálními př́pravky. In. Sborník referátú ze semináře: Faktorová onemocnění v chovu a výkrmu prasat, Lhenice 10.-11. 11. 1976. Praha, Agroplan 1977: $27-31$.

DUNCOMBE, W. G.: The colorimetric micro-determination of nonesterified fatty acids in plasma. Clinica chim. Acta, 9, 1964: 122-125.

DVORÁK, M. - RASZYK, J.: Effect of insulin hypoglycaemia on adrenocortical function and blood plasma vitamin $\mathrm{E}$ and cholesterol levels in suckling and weaned piglets. Physiol. bohemoslov., 25, 1976: 7-11.

LANDON, J. - JAMES, V. H. T. - STOKER, D. J.: Plasma-cortisol response to lysine vasopressin. Lancet II, 1965: 1156-1159.

MATTINGLY, O.: A simple fluorimetric method for the estimation of free 11-hydroxycorticosteroids in human plasma. J. clin. Path., 15, 1963: 374-379.

OTA, K. - HARAI, Y. - UNNO, H. - SAKAUCHI, S. - TOMOGANE, H. - YOKOYAMA, A.: Corticosterone secretion in response to suckling at varions stages of normal and prolonged lactation in rats. J. Endocr., 62, 1974: 679-680.

PEARSON, S. - STERN, S. - Mc GAVACK, T. H.: A rapid accurate method for the determination of total cholesterol in serum. Analyt. Chem., 25, 1953: 813-814.

PURVES, H. D. - SIRETT, N. E.: The fluorimetric estimation of cortisol in human plasma Aust. J. exp. Biol. med. Sci., 47, 1969: 589-599.

RASZYK, J. - CANDERLE, J. - DVOKÁK, M.: Změny vybraných metabolických ukazatelủ při syndromu metritis-mastitis-agalactie u prasnic. In: Sborník referátů ze semináře: Faktorová onemocněni $v$ chovu a výkrmu prasat, Lhenice 10.-11.11. 1976. Praha, Agroplan 1977: 7-16.

ROSS, R. F. - ZIMMERMAN, B. J. - WAGNER, W. C.: A field study of coliform mastitis in sows. J. Am. vet. med. Ass., 167, 1974: 231-235.

STAJNER, A. - SƯVA, J.: Př́íspěvek ke stanovení neesterifikovaných mastných kyselin v krevním séru. Čs. Fyziol., 24, 1975: 247.

STERN, J. M. - LEVINE, S.: Pituitary-adrenal activity in the postpartum rat in the absence of suckling stimulation. Horm. Behav., 3, 1972: 237-246.

THOMPSON, J. N. - ERDODY, P. - BRIEN, R. - MURRAY, T. K.: Fluorometric determination of vitamin $A$ in human blood and liver. Biochem. Med., 5, 1971: 67-89.

THOMPSON, J. N. - ERDODY, P. - MAXWELL, W. B.: Simultaneous fluorometric determinations of vitamins $A$ and $E$ in human serum and plasma. Biochem. Med., 8, 1973: 403-414.

THREEFALL, W. R. - DALE, H. E. - MARTIN, C. E.: Serum and adrenohypophyseal concentrations of prolactin in sows affected with agalactia. Am. J. vet. Res., 35, 1974: 313-315.

WAGNER, W. C.: Endocrine function in normal and agalactic sows. J. Anim. Sci., 34, 1972: $270-272$. 